\title{
PARA ALÉM DA ILUSÃO: O REAL NA CRÍTICA FREUDIANA À RELIGIÃO
}

Claudia Maria Silva Moreira e Jeferson Machado Pinto

Claudia Maria Silva

Moreira

Psicanalista, mestre em psicologia pela UFMG.

Jeferson Machado Pinto Psicanalista, doutor em Psicologia pela USP, professor associado departamento de Psicologia da UFMG.

RESUMO: Pretende-se demonstrar como a matriz primeira de interpretação freudiana da religião — baseada na crítica aos elementos imaginários que compõem o quadro da adesão religiosa — é suplantada por Freud com a escrita de Moisés e o monoteísmo em 1939. É a leitura deste ensaio que nos permite perceber a presença do real na genealogia da religião. O sentimento de desamparo vinculado à experiência de satisfação foi alvo de nossa investigação, fornecendo subsídios que confirmaram a presença de outros elementos além dos imaginários no fenômeno religioso.

Palavras-chave: Religião, ilusão, desamparo, real, Moisés.

ABSTRACT: Beyond Illusion: the Real in Freud's criticism to religion. This paper aims to demonstrate how the first religious interpretative Freud's matrix - based on the criticism of imaginary elements that constitute the framework of the religious adhesion — is overcome by Freud's Moses and the Monotheism in 1939. This reading allows us to realize the presence of the Real in the genealogy of religion. The analysis of the feeling of helplessness combined with the experience of satisfaction was also investigated here, providing subsidies that confirm the presence of other elements beyond the imaginary in the religious phenomenon.

Keywords: Religion, illusion, helplessness, real, Moses. 
$\mathrm{P}$ or meio do exame crítico da religião, Freud apresenta uma explicação que denuncia os aspectos excessivamente imaginários que compõem o quadro da adesão religiosa. Mas essa explicação parece não se configurar como suficiente. A recorrência do tema da religião nos escritos freudianos é prova inconteste disso. Encontramos ao longo de toda a obra freudiana, bem como em sua correspondência pessoal, numerosas referências à religião, citações esparsas, comentários importantes inseridos em um caso clínico e até um estudo dedicado à análise e discussão de uma vivência de cunho religioso - estamos nos referindo ao texto Uma experiência religiosa, de 1927.

Em El psicoanálisis freudiano de la religión: Analisis textual y comentario crítico (1990), Morano coleta todas as citações sobre religião no decorrer da obra freudiana. Este levantamento é fundamental porque atesta que o tema é legitimamente recorrente. A questão da religião parece não se esgotar para Freud. Essa inquietação revelada pelas constantes alusões e ensaios dedicados ao assunto deve ser tomada como um indício de que algo nessa discussão restou irresoluto na análise crítica freudiana endereçada à religião. Mijolla-Mellor sustenta a hipótese de que essa recorrência da preocupação sobre o fenômeno religioso em Freud:

“(...) se devia claramente ao fato de que a análise teórica, endossada pela antropologia e pela história, não lhe parecia suficiente, obrigando-o a continuar sempre buscando, o que ele só deixará de fazer com o texto sobre Moisés e sua morte” (MIJOLLA-MELLOR, 2004, p.270).

Mas a razão pela qual Freud permanece interessado na questão - a ponto de morrer pensando nisso ${ }^{1}$ — não pode ser de todo creditada a um embasamento histórico e antropológico pouco consistente. Parece-nos que o interesse freudiano em relação à religião deve ser pensando sempre em proporção direta à sua inquietação com a questão paterna, pois para Freud, a religião implicava a existência do pai. Com Totem e Tabu (1912-1913) e a ideia do assassinato primevo gerando culpa e ambivalência afetiva em relação ao pai, não teríamos uma solução razoável no que tange à origem da religião? Por que ainda assim Freud permanece empenhado nessa questão a ponto de retomá-la um quarto de século depois em Moisés e o Monoteísmo (1939)?

A escrita de Moisés e o Monoteísmo deve ser tomada como o último esforço freudiano em apreender algo sobre o fato religioso. A produção deste ensaio, ao final de sua vida, comporta uma mensagem de que algo ainda se fazia necessário investigar para o próprio Freud no tocante à religião. Nosso intuito neste artigo

\footnotetext{
${ }^{1}$ Moisés e o Monotésmo (1938) é praticamente um dos últimos textos escritos por Freud antes de sua morte.
} 
é demonstrar que em Moisés e o monotésmo Freud ultrapassa o paradigma da ilusão como matriz primeira de interpretação psicanalítica da religião.

\section{O VIGOR DA ILUSÃO}

Por que as ideias religiosas têm tanta força independente do reconhecimento pela razão de seu caráter ilusório? Essa é a questão que se coloca para Freud ao longo de $\mathrm{O}$ futuro de uma ilusão:

"as ideias religiosas, a despeito de sua incontrovertível falta de autenticidade, exerceram a mais forte influência possível sobre a humanidade. Trata-se de um novo problema psicológico. Devemos perguntar onde reside a força interior dessas doutrinas e a que devem sua eficácia, independente, como é, do reconhecimento pela razão" (FREUD, 1927/1996, p.38).

A resposta forjada por Freud para compreender esse "novo problema psicológico" está assentada sob a noção de ilusão e sua correlação com o sentimento de desamparo infantil e o complexo paterno. As ideias religiosas têm tanto vigor porque "são ilusões, realizações dos mais antigos e prementes desejos da humanidade. O segredo de sua força reside na força desses desejos" (FREUD, 1927/1996, p.39). Freud faz inicialmente uma distinção entre ilusão e delírio. A faceta essencial da ilusão é que ela deriva de desejos humanos que em princípio não estariam na mente em contradição com a realidade. Já a ideia delirante estaria em desacordo com a realidade externa.

Mas o aspecto a salientar é que existem ilusões tão carregadas de desejo que acabam por desprezar as relações com a realidade. É o caso do religioso que acredita na vinda de um novo Messias. O que fica evidente é que as nuanças entre ilusão e delírio no que tange à religião vão se tornando cada vez menores ao longo de $O$ futuro de uma ilusão. A religião abrangeria assim "um sistema de ilusões plenas de desejo juntamente com um repúdio da realidade” (FREUD, 1927/1996, p.52).

A noção de ilusão por sua vez irá conectar-se ao sentimento de desamparo. A origem psicológica das ideias religiosas é explicada a partir do sentimento de desamparo infantil vivido pela criança e pela proteção encontrada na figura do pai. Em um primeiro momento, a mãe era o objeto amoroso capaz de proporcionar satisfação ao bebê. Mas, em seguida ela é substituída pelo pai, mais forte, que ocupará essa função durante toda a infância. Essa relação com o pai será marcada pela ambivalência. Ele será odiado por interferir-se na relação da criança com a mãe e admirado por sua força e capacidade de trazer segurança à 
criança - ela vai reconhecer na figura do pai o suporte necessário para protegêla e auxiliá-la em situações atemorizantes.

Já na fase adulta, o homem percebe que sua vida é fonte de enfrentamentos e dificuldades, e que sua condição diante dela ainda é frágil e o sentimento de desamparo continua presente. Mas, diferentemente da criança, o adulto reconhece agora que seu pai encontra-se no mesmo estado que o seu e não possui poderes irrestritos como outrora imaginara. A imagem de Deus é investida de amor tal como a criança na infância supervalorizava o pai. Foi por meio dessas considerações sobre a fonte psicológica das ideias religiosas que Freud concluiu que o conforto trazido pela religião não é outra coisa senão mera ilusão. O sentimento de desamparo infantil vivido pela criança deve ser apontado como a fonte psicológica das ideias religiosas e vinculado em primeira instância à necessidade do pai.

Essa é a essência da argumentação freudiana. A figura de Deus vem ocupar o lugar que um dia esteve preenchido pelo pai. A religião, nestes termos, seria uma reação de defesa contra o desamparo. Ocorre que essa é apenas uma parte da questão. Diante do desamparo, evocamos a proteção de um pai glorificado. Mas há outros efeitos provocados pelo sentimento de desamparo que não foram contemplados na análise crítica freudiana da religião e que discutiremos oportunamente.

O encaminhamento proposto em O futuro de uma ilusão é mais combativo apostando no abandono da religião em prol do advento da ciência como um projeto mais afeito à realidade — do que necessariamente clínico. Vale notar que ao mesmo tempo em que sustenta uma atitude de cunho racionalista frente à religião, Freud não deixa de salientar, no mesmo texto, o primado da vida pulsional em relação aos recursos disponíveis à razão. Este é o paradoxo de $O$ futuro de uma ilusão: a crítica freudiana incide sobre os aspectos ilusórios e imaginários presentes nas ideias religiosas, mas em contrapartida, Freud parece negligenciar que essas ideias "não constituem precipitados de experiências ou resultados finais de pensamento” (FREUD, 1927/1996, p.39), e sim intensos e fortes desejos.

Assim, como esperar a retirada imediata da libido uma vez declarado o caráter ilusório da religião? A pergunta que fica em suspenso ao final da leitura de O futuro de uma ilusão é se poderíamos supor - para além das considerações que colocam em evidência a presença maciça de aspectos imaginários — a existência de outros elementos que atuem efetivamente proporcionando a adesão às ideias religiosas. A resposta a esse questionamento será encontrada em Moisés e o monotéísmo (1939). 


\section{MOISÉS E O MONOTEÍSMO}

Miller afirma que foi sobre o pano de fundo de $O$ futuro de uma ilusão que Freud lançou sua mensagem mosaica que parece dizer: "essa ilusão tem um futuro" (MILLER, 2004, p.10). O comentário de Miller é importante porque reforça nossa hipótese de que em Moisés estamos diante de uma reformulação freudiana no que se refere à religião. Freud procura responder em Moisés e o monoteísmo de que maneira a ideia de um Deus único veiculada no monoteísmo judaico-cristão ingressou em nosso mundo. É assim que vemos surgir mais um mito freudiano sobre o pai.

Neste trabalho, Freud se aventura em uma reconstrução da história do povo judaico. A partir da análise etimológica do nome 'Moisés' - que deriva da palavra egípcia 'mose' que significa 'criança' — Freud fundamenta sua hipótese sobre a origem egípcia de Moisés. Mas considerar a origem egípcia do nome Moisés é bastante diferente de qualificar o próprio Moisés como egípcio. Este é o passo que Freud dá com base nas contradições entre a lenda do nascimento de Moisés e a análise dos mitos segundo o modelo proposto por Oto Rank em Mito do nascimento do herói. A análise freudiana conclui que a lenda do nascimento de Moisés foi inventada para transformá-lo em um judeu. A vida heroica de Moisés começou com ele descendo de sua posição elevada ao nível dos filhos de Israel (FREUD, 1939/1996, p.19-70).

Se Moisés deu uma religião ao povo judeu, essa religião poderia ser egípcia? A religião egípcia e a religião mosaica em nada se assemelhavam. Na primeira havia uma proliferação de deuses, magias, encantamentos e amuletos e era professada a crença em outro mundo após a morte. A segunda, por sua vez, era monoteísta. Havia um único deus onipotente e nenhuma imagem deste deus deveria ser feita, seu nome sequer poderia ser pronunciado. Como levar adiante a postulação da origem egípcia de Moisés frente a essa contradição que apresentava duas religiões tão díspares?

Freud recorre à história e à antropologia e não se detém diante deste obstáculo. É no Egito, na XVIII dinastia, por volta de 1375 a.C., que encontramos a primeira forma de monoteísmo estrito de que se tem notícia. Tal fato ocorreu quando o jovem faraó Amenófis IV subiu ao trono. Este faraó se converteu ao culto solar de On, que concebia a ideia de um deus universal. Amenófis IV muda seu nome para Akhenaten e funda a religião de Aten. Nessa religião não havia adoração do sol como um objeto material e sim como símbolo de um ser divino cuja energia se manifestava em seus raios. "Não é o próprio corpo celeste que é adorado, mas o ser que nele se revela" (ERMAN, 1905, p.66 apud FREUD, 1939/1996, p.35).

O propósito freudiano era destacar as semelhanças existentes entre a religião de Aten e a religião mosaica e desta forma reunir condições para supor que Moisés era um aristocrata egípcio que vivia na corte de Akhenaten. Após a morte do 
faraó, insatisfeito com o retorno do politeísmo e totalmente imbuído da religião de Aten, Moisés escolhe os judeus para transmitir essa religião.

Depois de apresentar as principais considerações que justificariam a origem egípcia de Moisés - análise etimológica do nome, mito do nascimento do herói e semelhança entre a religião de Aten e a religião mosaica — Freud passa a discutir o trabalho de dois historiadores: E. Meyer e Ernest Sellin. Como diz Morano, "assim como quem interpreta um sonho Freud abandona esse fio do material para acudir a outro que ainda não fora explorado por ele" (MORANO, 1991, p.312).

Os estudos de E. Meyer indicavam que a origem da religião judaica estava associada ao culto do Deus Javé na região de Meribá-Cades. As tribos judaicas que mais tarde viriam a formar o povo de Israel, nesta época adoravam o deus Javé em um local próximo ao sul da Palestina. O Moisés descrito por Meyer seria um pastor, genro do sacerdote midianita Jetro. O deus Javé por sua vez, em nada se assemelhava àquele deus de Aten espiritualizado. Javé era um deus meio demônio dos vulcões, afeito a todo tipo de magia. "Javé era um demônio sinistro e sedento de sangue, que vagueava pela noite e evitava a luz do dia" (MEYER apud FREUD, 1939/1996, p.49).

Para Meyer, a religião judaica não teria nascido no Egito como aventou Freud e muito menos no Monte Sinai, como a tradição afirma. O que este autor procura enfatizar é a vinculação estreita entre Moisés e a região de Meribá-Cades. O Moisés de Meyer é tão somente um pastor a quem o deus Javé se revelou.

De posse dessas informações tão incongruentes acerca de Moisés, Freud lança mão da tese descrita na monografia de Sellin em 1922. Segundo Freud, Sellin encontrou fortes indícios de que o fundador da religião dos judeus havia sido brutalmente assassinado em "um levante de seu povo refratário e obstinado, ao mesmo tempo em que a religião por ele introduzida era repudiada” (FREUD, 1939/1996, p.52).

A consequência que Freud vai extrair a partir da análise da tese de Sellin é genial ou absurda, dependendo do ângulo do qual a contemplamos: não existiu um Moisés e sim dois! Genial porque, neste processo de duplicação de Moisés, percebemos o intento de Freud em demonstrar o surgimento do monoteísmo atrelado àquilo que escapa à representação e é traumático, a algo que está além do sentido. Absurdo porque ao sustentar seu trabalho como uma reconstrução de cunho histórico sem elementos consistentes ou como afirma Morano - ao se aventurar em "uma reconstrução global da história de Israel, deixando de lado os dados dos historiadores” (MORANO, 1990, p.314) — Freud fica vulnerável a todo tipo de crítica e é duramente censurado. É evidente que ele estavamente cônscio deste risco, tanto é assim que a primeira nota preambular escrita em Viena, em março de 1938, inicia-se do seguinte modo: "com a audácia daquele 
que tem pouco a perder". A tese do assassinato de Moisés era uma peça chave para Freud. Quando algum tempo depois ele foi informado que o próprio Sellin havia recuado quanto ao seu argumento central, Freud não se fez de rogado e afirmou que a história do 'segundo Moisés' era uma invenção sua (GAY, 1989).

Devemos salientar aqui o modo analítico pelo qual o trabalho freudiano de reconstrução se efetiva. Não se trata de determinar cientificamente o que de fato aconteceu ao longo da história do povo judaico. Freud trabalha a partir de vestígios, fragmentos, elementos opacos que não foram integrados ao corpo histórico, deixando lacunas. É em razão deste processo que podemos entender o lugar "eminente que Freud atribui à função do traumatismo em sua genealogia da religião monoteísta” (MILLER, 2004, p.21). As marcas deixadas pelo assassinato de Moisés portam um excesso impossível de assimilar. Conforme observa Lo Bianco:

\footnotetext{
“[Freud] procura recuperar com base nas mais variadas fontes, atrás dos mais antigos relatos e dos mais diminutos detalhes os 'fósseis de referência' (p.38), o acontecer histórico (Geschichte) que lhe permitisse construir a história da fundação da religião judaica. (...) Recorta por seu procedimento um real para a religião mosaica ao procurar dar as bases da tradição que a tornou possível — tradição que garantiu a transmissão do trauma vivido pelo povo judeu" (LO BIANCO, 2007, p.130).
}

O mito de Moisés pode ser lido, portanto, como o modo freudiano de se falar do real. Neste sentido não é mera casualidade que o Moisés fabricado por Freud seja estrangeiro, i.e., um elemento estranho, exterior à ordem simbólica estabelecida.

\section{A TRANSMISSÃO DO TRAUMA: RELIGIÃO E SINTOMA}

$\mathrm{Na}$ reconstrução levada a cabo por Freud, o primeiro Moisés era egípcio e professava a tradição religiosa enlaçada ao deus Aten. Este primeiro Moisés foi assassinado e mais tarde substituído por um segundo Moisés, o pastor midianita, que Meyer descreveu como vinculado ao Deus Javé na região de Meribá-Cades. A hipótese freudiana conciliaria as descrições tão díspares a respeito de Moisés. A nação judaica seria fruto de duas tendências distintas que depois daria lugar aos dois reinos: 'Israel' e 'Judá'.

Como os seguidores do Moisés egípcio haviam abandonado a religião de Aten, as tribos judaicas que se encontravam na região de Cades adotaram a religião de Javé, mas a tribo dos Levitas permaneceu fiel à religião prescrita pelo Moisés egípcio. Uma espécie de acordo foi selado em Cades, buscando harmonizar as diferenças existentes entre esses dois povos. O deus Javé restrito à região de 
Meribá-Cades, cujo caráter era violento e ordinário, transforma-se, em um período de várias gerações, em um deus único e universal. O que vemos aqui é que a reconstrução freudiana da história de Israel apoia-se no mesmo modelo de formação de um sintoma.

“A história judaica nos é familiar por duas dualidades: dois grupos de pessoas que se reúnem para formar a nação, dois reinos em que essa nação se divide, dois nomes de deuses nas fontes documentárias da Bíblia. A elas, acrescentamos outras duas, novas: a fundação de duas religiões - a primeira reprimida pela segunda, não obstante emergindo depois vitoriosamente, por trás dela, e dois fundadores religiosos, ambos chamados pelo mesmo nome de Moisés e cujas personalidades temos de distinguir uma da outra. Todas essas dualidades são as consequências necessárias da primeira: o fato de uma parte do povo ter tido uma experiência que tem que ser considerada como traumática, à qual a outra parte escapou." (FREUD, 1939/1996, p.69)

Freud concebe a perpetuação e a transmissão do monoteísmo, desde o reinado de Akhenaten no Egito, passando pela história de Israel até chegar ao cristianismo como um acontecimento calcado no assassinato. Em outras palavras, o Um se inscreve no mundo a partir do traumatismo. A tese central freudiana é de que a origem da religião monoteísta é equivalente à origem dos sintomas neuróticos. A etiologia de uma neurose está invariavelmente relacionada ao trauma. Trauma compreendido aqui como algo que escapa radicalmente, impedindo sua assimilação por parte do sujeito. O mesmo protótipo encontrado no plano individual da subjetividade: trauma primitivo — defesa — latência — desencadeamento da doença neurótica — retorno parcial do recalcado é transposto para o plano geral da história da humanidade. De acordo com Lo Bianco:

"[Freud localiza o trauma como] o mesmo conceito que fala das marcas precoces infantis; que se refere às marcas feitas no corpo por impressões vistas e ouvidas que não podem fazer parte das associações, que não são significantizáveis, não são articuláveis - como o ponto em torno do qual virá a ser elaborada a história do sujeito, tanto quanto a história da cultura ou de uma religião como o judaísmo. Sendo impossível conviver com essas marcas por sua intensidade, pelo excesso que portam, pelos seus efeitos de ruptura, por sua insistência, elas serão desmentidas. No entanto, mesmo assim, ficam como cicatrizes" (LO BIANCO, 2007, p.130).

Os fenômenos da religião seriam semelhantes em sua estrutura e finalidade aos sintomas neuróticos. O evento traumático a que se refere Freud é o assassinato do pai primevo. O esquecimento do assassinato pelas gerações seguintes corres- 
ponde ao recalque. O tempo transcorrido entre o assassinato do pai primevo até o surgimento do monoteísmo corresponde ao período de latência, ou seja: há uma temporalidade retroativa própria à causalidade do sintoma. O surgimento do monoteísmo, a crença em um deus universal é o retorno do recalcado: o restabelecimento do pai primevo. Na história do judaísmo, o fator precipitante desse retorno do recalcado foi o assassinato do Moisés egípcio. Toda essa construção revela que Freud transpõe o paradigma da ilusão em Moisés, pois, ao atrelar a gênese do monoteísmo judaico a um evento traumático, estamos diante do real. Dizer que o traumatismo está na gênese da religião é dizer que o real está em jogo na gênese da religião judaica. De acordo com Fink:

"Uma das faces do real com que lidamos na psicanálise é o trauma. Se pensarmos o real como tudo aquilo que ainda não foi simbolizado, a linguagem sem dúvida nunca transforma completamente o real, nunca suga tudo do real para dentro da ordem simbólica; fica sempre um resto (...) o trauma sugere fixação ou bloqueio. A fixação sempre envolve algo que não é simbolizado.” (FINK, 1998, p.45)

Para além de toda a querela suscitada pela audácia da hipótese freudiana interessa-nos antes tentar circunscrever o que estaria em jogo neste texto tão inventivo e surpreendente a respeito da religião. Se em O futuro de uma ilusão Freud argumenta que a religião é uma ilusão, cuja fonte, em última instância, é a necessidade de proteção em função do desamparo, em Moisés e o monoteísmo, Freud amplia o escopo da crítica à religião. Para além da ilusão, a religião possui a estrutura de um sintoma e enquanto tal há um ponto incontornável. A própria noção de história é modificada: se antes era vista como um processo progressivo que culminaria no "esclarecimento" das pessoas e consequente abandono da visão religiosa do mundo, agora em Moisés com a ideia de trauma e retorno do recalcado incidindo também sobre a história humana, o que vemos é o surgimento da história marcada pela descontinuidade, em que o conceito de latência e a causalidade retroativa cumprem uma função importante. Se antes as ideias religiosas eram caracterizadas como ilusão e delírio, agora podemos assinalar uma espécie de concessão feita por Freud ao se referir à ideia de um deus único:

"Uma ideia como essa possui um caráter compulsivo: ela deve ser acreditada. Até o ponto em que é deformada, ela pode ser descrita como um delírio; na medida em que traz um retorno do passado, deve ser chamada de verdade. Também os delírios psiquiátricos contêm um pequeno fragmento de verdade." (FREUD,1939/1996, p.154) 
O que está em questão nessa passagem é que para Freud a religião² conteria um núcleo de verdade histórica que remontaria ao assassinato do pai. Ao introduzir a figura do Moisés egípcio assassinado em conexão direta com a história judaica, Freud institui no seio dessa tradição o elemento capaz de explicar a perpetuação da religião em nosso mundo. Parece-nos que o processo de duplicação de Moisés evidencia uma divisão (Spaltung) acarretada pelo trauma e encoberta pelo sintoma. É neste contexto que Freud irá novamente questionar de quais fontes as ideias religiosas derivam seu poder de subjugar tantos homens. Há uma diferença na concepção da ideia de deus que devemos assinalar. Em O futuro de uma ilusão, Deus era imaginado como um pai protetor e por essa razão seria capaz de proporcionar segurança e amparo a seus filhos.

É neste ponto que Freud localiza a fonte principal da necessidade religiosa. Mas em Moisés estamos diante de um Deus misturado. O Deus que o Moisés egípcio representava era completamente diferente do deus Javé idolatrado pelo Moisés Midianita. Esses deuses tão diferentes se confundem na composição do deus único do monoteísmo judaico. Perante o estado de desamparo podemos invocar um deus protetor, mas é preciso lembrar que esse mesmo deus surge como um ente terrível, feroz e violento, fora de uma mediação através do simbólico.

De acordo com Teixeira,

“A versão pacificante e benigna de um Moisés egípcio aponta para a vertente do Pai como princípio de regulação simbólica, exemplificada na interdição do culto à imagem e na espiritualidade de Deus Aton [Aten], a versão suplementar de um

\footnotetext{
${ }^{2}$ Para Freud, o monoteísmo judaico se difere em muitos aspectos do monoteísmo cristão. Mas, um estudo pormenorizado sobre as diferenças entre judaísmo e cristianismo foge ao escopo deste artigo. Cabe esclarecer que o traumático será tratado como real pelo judaísmo e como uma representação pelo cristianismo (na figura de Cristo). Para fundamentar nossa hipótese de que Freud ultrapassa o paradigma da ilusão em sua análise crítica da religião, interessa-nos enfatizar o real presente na fundação da religião judaica e a repercussão de tal fato na ideia de um deus único. Freud considera que o remorso pelo assassinato de Moisés

"forneceu o estímulo para a fantasia de desejo do Messias, que deveria retornar e conduzir seu povo à redenção e ao prometido domínio mundial. Se Moisés foi o primeiro Messias, Cristo tornou-se seu substituto e sucessor, e Paulo poderia exclamar para os povos com certa justificação histórica: 'Olhai! O Messias realmente veio: ele foi assassinado perante vossos olhos!' Além disso, existe um fragmento de verdade histórica na ressurreição de Cristo, pois ele foi o Moisés ressureto e, por trás deste, o pai primevo retornado da horda primitiva, transfigurado e, como filho, colocado no lugar do pai." (FREUD, 1939/1996, p.110)

Mas a morte de Cristo na cruz foi compreendida como um sacrifício que possibilitou aos homens a remissão do "pecado original". Pecado original interpretado por Freud como o assassinato do pai, este seria na verdade o "crime original". O sacrifício de Jesus teria permitido aos cristãos expiarem toda a culpa pelo assassinato do pai, ao passo que os judeus tomaram para si uma enorme carga de culpa.
} 
intransigente e irascível Moisés madianita [midianita] vem expor, na ferocidade do deus Yahvé [Javé] que ele representa, o que há de real para além da mediação simbólica, a violência da Lei.” (TEIXEIRA, 2007, p.109)

Essa modificação introduzida na própria composição de Deus — duas figurações que se misturam e se confundem — não é sem consequências para pensarmos o estatuto da crítica freudiana à religião. Se antes a aderência às ideias religiosas se justificava em função de um vínculo excessivamente imaginário com a figura de Deus-pai, agora podemos pensar que a fonte psíquica da necessidade religiosa pode estar atrelada, também, àquilo que surge como traumático e violento. Este aspecto talvez tenha permanecido camuflado e obscuro por trás da ideia de um deus protetor a que poderíamos recorrer diante do desamparo. Freud recupera esse ponto em seu Moisés e o integra na origem mesma do monoteísmo judaico. Esse deus como formação de compromisso que encontramos em Moisés é, assim como o sintoma, uma operação de superposição do simbólico frente ao real. Operação fadada ao fracasso, uma vez que é impossível recobrir totalmente o real.

\section{O CARÁTER REAL DO DESAMPARO}

A partir do que apresentamos, reunimos condições para resgatar e examinar uma passagem em O mal-estar na civilização (1930) que irá confirmar nossa tese sobre a existência de outros elementos que justificariam a adesão religiosa para além dos aspectos imaginários discutidos e elencados por Freud em O futuro de uma ilusão. Trata-se de um trecho em que encontramos a definição da origem psíquica da ideias religiosas: "a origem da atitude religiosa pode ser remontada, em linhas muito claras, até o sentimento de desamparo infantil. Pode haver algo mais por trás disso, mas presentemente, ainda está envolto em obscuridade" (FREUD, 1930/1996, p.81).

Esse "esse algo a mais (...) envolto em obscuridade" merece destaque porque nos principais estudos dedicados ao tema, a análise do fato religioso leva em consideração apenas a primeira parte da afirmativa freudiana, ou seja, situa a fonte psicológica da religião a partir do desamparo (ver MORANO, 1990). Iremos explorar a segunda parte da afirmativa freudiana - aquela que aventa a possibilidade de existência de algum ponto obscuro por trás do sentimento desamparo. A esse respeito é importante afirmar ainda que esse ponto "obscuro" ao qual Freud faz menção pode estar relacionado a uma opacidade inerente ao próprio sujeito. Nestes termos, o estudo e a crítica à religião poderiam ser pensados como um recurso metodológico freudiano para apreender algo que seria inerente à nossa própria constituição subjetiva. 
No interior da elaboração freudiana, a palavra Hilflosigkeit - desamparo assume uma acepção peculiar. Ela traduz o estado de dependência completa e irrestrita em que se encontra o bebê para a satisfação de suas necessidades. Sem a ação adequada de Outro, o bebê é incapaz de apaziguar a tensão interna provocada pela fome, sede, frio. Essa dependência total do bebê implica contrapartida na onipotência deste Outro. O bebê não sabe lidar com todos os estímulos endógenos que emanam de seu corpo, i.e., com o real da pulsão. É o Outro (muitas vezes na figura da mãe) que poderá deter esse processo proporcionando um apaziguamento da tensão. Através do choro e do grito, o bebê faz apelo àquele que ele localiza como o agente de seus cuidados. O Outro surge imaginariamente como absoluto. É neste contexto que devemos situar a afirmativa freudiana de que "o desamparo inicial dos seres humanos é a fonte primordial de todos os motivos morais" (FREUD, 1895/1996, p.370).

Esse arranjo inicial que acabamos de descrever vai interferir de forma decisiva na estruturação do psiquismo que se constituirá primariamente nessa relação de dependência ao Outro. Essa é a principal implicação da noção de desamparo: a realidade exterior será apreendida a partir do Outro.

Esse estado de desamparo inicial estará irremediavelmente ligado à experiência de satisfação na medida em que apenas o Outro será capaz de realizar uma ação específica que apaziguará a tensão interna gerada por algum tipo de necessidade no bebê. É a eliminação da tensão que provoca a experiência de satisfação. Mas há ainda uma importante consequência resultante da vivência de satisfação que devemos analisar: trata-se do fato de que essa vivência deixa um resíduo não assimilável: das Ding. Quando Freud discorre sobre o sentimento de desamparo infantil como causa originária da necessidade religiosa não leva em conta que o estado de desamparo vincula-se diretamente à experiência de satisfação e que nessa última há um ponto incontornável.

O bebê não pode restaurar ou reunir em nenhum outro objeto essa percepção originária provocada por das Ding. O objeto que miticamente proporcionou a satisfação plena restará para sempre perdido. É nessa experiência fundadora da subjetividade que o bebê irá perceber que é separado do outro e ao mesmo tempo há algo desconhecido nesse outro ao qual ele permanece unido. Das Ding é ao mesmo tempo algo inapreensível, impossível de resgatar, que escapa completamente à função do juízo, e em contrapartida é a parte constante do complexo do próximo, ou seja, há desde sempre um vazio permanente impossível de se representar. Conforme Lacan: “É aqui que intervém essa realidade que tem relação com o sujeito da maneira mais íntima — o Nebenmensch. Fórmula totalmente surpreendente na medida em que articula energicamente o à-parte e a similitude, a separação e a identidade (LACAN, 1959-1960/1991, p.68). 
Esse estranho objeto, impossível de ser nomeado, que surge como alteridade primeira, das Ding vai provocar o engajamento desejante do sujeito para reencontrá-lo. Não há objeto capaz de instaurar-se como completo correlato das necessidades e dos desejos humanos, mas o sujeito continuará procurando reencontrar o objeto primeiro. É a perda “mítica” desse objeto primeiro que servirá como guia a orientar a escolha por outros objetos. Das Ding é o objeto estranho, desconhecido, mas é também o objeto mais ansiado.

Atingir das Ding é da ordem do impossível. O que Freud evidencia através da experiência de satisfação é que não há Bem Supremo. A completude é imaginária. O comentário feito por Lacan de que deveríamos considerar a oposição entre principio de prazer e princípio de realidade - postulada por Freud acerca do aparelho psíquico - menos como algo da ordem psicológica e mais como algo da ordem ética, se esclarece a partir dessa consideração. Nossa subjetividade é instituída sobre um fundo de conflito irreconciliável e o resultado dessa dinâmica é que o objeto capaz de satisfazer plenamente o sujeito é estruturalmente perdido. Freud afirma em O mal-estar na civilização:

“Ficamos inclinados a dizer que a intenção de que o homem seja ‘feliz’ não se acha incluída no plano da 'Criação'. O que chamamos de felicidade no sentido mais restrito provém da satisfação (de preferência, repentina) de necessidades represadas em alto grau, sendo por natureza, possível apenas como uma manifestação episódica. Quando qualquer situação desejada pelo princípio de prazer se prolonga, ela produz tão somente um sentimento de contentamento muito tênue.” (FREUD, 1930/1996, p.84)

O que esse fragmento revela é que não fomos 'criados' para alcançar a satisfação plena. Só desejamos porque estruturalmente há um vazio, um irrepresentável: das Ding é esse furo impossível de preencher e ao mesmo tempo é em torno desse furo que o sujeito irá se constituir.

Ora, diante do que apresentamos, podemos afirmar que Freud considera o sentimento de desamparo como fonte das necessidades religiosas, apenas do ponto de vista imaginário e simbólico. O pai — depois transposto para a figura de Deus - surge como aquele capaz de proporcionar conforto e segurança. Essa posição é a mesma ocupada pelo pai na trama edípica. É a intervenção paterna que possibilitará à criança inscrever-se em um novo lugar como sujeito desejante. Mas, como foi possível demonstrar, há ainda outra face a ser explorada. Há um resto inassimilável — fora do significado, um elemento extralinguístico - presentificado por das Ding. A função simbólica do pai nunca será suficiente para recobrir esse ponto desconhecido, desejado e temido pelo sujeito. 
Este aspecto não contemplado de forma explícita por Freud em sua crítica à religião retornou ao final de sua vida na escrita difícil, lacunar e hesitante de seu Moisés e o Monoteísmo. Moisés é o estrangeiro - elemento que não será integrado - e, no entanto, é a partir dele que a nação judaica se funda enquanto tal. Lembremos que o estado de desamparo e a vivência de satisfação tal qual tivemos oportunidade de examinar são experiências estruturantes, precursoras de nossa constituição subjetiva. Das Ding é o resíduo dessa operação e pode ser concebido como o "ponto ainda envolto em obscuridade" relacionado ao sentimento de desamparo mencionado por Freud. Este aspecto não aparece integrado à crítica freudiana da religião que se fecha na questão do complexo paterno. De acordo com André Wénin:

"Quando preciso explicar o que Deus representa no discurso bíblico, a aproximação mais correta a meus olhos é precisamente esta. Este 'Deus' representa um não sei que que escapa radicalmente às apreensões do humano e que permite ao humano ser aquilo que é, coletiva e individualmente. No início do Gênesis - é assim que o evangelho de João interpreta - lê-se que no começo era a palavra. Mas de onde vem a palavra? De onde vem a linguagem? E a Bíblia nos responde: de Deus, quer dizer precisamente disso que é inapreensível.” (WÉNIN, 2008, p.13)

De onde vem a palavra? De onde vem a linguagem? A psicanálise nos responde: de das Ding. A figura de Deus condensaria esse algo que escapa radicalmente. Esse ponto poderia ser correlacionado ao real da ilusão, conforme observa Zizek, essa dimensão real na ilusão seria o “'real imaginário’ (o misterioso je ne sais quoi, o ‘algo' insondável que introduz uma divisão autoimposta em um objeto ordinário, permitindo assim que a dimensão do sublime brilhe através dele)" (ZIZEK, 2003, p.173). Ainda Zizek: “O que está efetivamente ‘para além da imagem’ é aquele X que faz do Homem Cristo um Deus” (idem, p.177). Estaria aí a força da religião para além da ilusão.

Lacan concebe o fenômeno da religião a partir da relação com o vazio deixado por das Ding. Para ele, a religião “respeitaria” esse vazio (LACAN, 19591960/1991, p.162). Mas a recuperação da Coisa via religião seria impossível uma vez que o sujeito não seria capaz de encontrar uma palavra capaz de exprimir esse irrepresentável.

Quando Lacan afirma que a religião respeita o vazio podemos interpretar essa reverência como uma manobra que visa o preenchimento do vazio através da figura de Deus. Essa primeira interpretação é passível de se afirmar se levarmos em conta que muitas vezes a religião oferta sentido visando preencher a divisão do sujeito. Sem dúvida, podemos inferir que Freud era partidário dessa concepção 
que vê a operação religiosa como uma espécie de sutura capaz de tamponar a falta inerente a todo ser falante.

Vem daí a crítica à religião como ilusão. Mas poderíamos ainda supor uma segunda vertente de interpretação que não consideraria deus como figura obturadora e sim como enigma. Nessa vertente, deus estaria no lugar do sem sentido, daquilo que não sabemos o que é. Se aceitássemos o fato de que deus está fora do sentido, nossa relação com esse "vazio de representação” longe de ser apenas de reverência poderia ser semelhante ao Che Vuoi? O "que queres" nessa dimensão articularia para o sujeito algo de seu desejo. Lacan em seus seminários $A$ ética da psicanálise (1959-1960) e A transferência (1960-1961), afirma que os deuses seriam um modo de revelação do real, no sentido em que designam este limite de significação do simbólico, este "furo no saber". Deus seria assim um dos nomes do objeto perdido.

Na primeira vertente, a religião teria uma função obliteradora, tamponando a castração com o sentido. Essa vertente é discutida e trabalhada por Freud de modo exaustivo. Mas, para além do viés imaginário, na segunda vertente, DeusPai surgiria como objeto, das Ding, causa de desejo e desconhecido por excelência. Estaríamos assim acrescentando outro elemento à crítica freudiana à religião capaz de explicar a força e a insistência da religião a despeito dos argumentos lógicos. A relação íntima de Deus com o Real é o que daria à religião seu caráter irredutível.

Recebido em 23/6/2009. Aprovado em 25/1/2010.

\section{REFERÊNCIAS}

FREUD, S. (1996) Edição standard brasileira das obras psicológicas completas de Sigmund Freud. Rio de Janeiro: Imago.

(1895) "Projeto para uma psicologia científica”, v.I, p.335-469.

(1913 [1912-13]) “Totem e tabu”, v.XIII, p.13-162.

(1927) "O futuro de uma ilusão”, v.XXI, p.15-61.

(1930 [1929]) “O mal-estar na civilização”, v.XXI, p.67-148.

(1939 [1934-38]) “Moisés e o monoteísmo”, v.XXIII, p.13-161.

FINK, B. (1998) O sujeito lacaniano; entre a linguagem e o gozo. Rio de Janeiro: Jorge Zahar.

GAY, P. (1989) Freud: uma vida para nosso tempo. São Paulo: Companhia das Letras, 1989. 
LACAN, J. (1959-1960/1991). O Seminário. Livro 7, A ética da psicanálise. Rio de Janeiro: Jorge Zahar.

(1960-1961/1999) O seminário, livro 8, A transferência. Rio de Janeiro: Jorge Zahar.

LEBRUN, J. P., WÉNIN A. (2008). Des lois pour être humain. Paris: Éres.

LO BIANCO, A. C. (2007) O que a comparação entre a tradição religiosa e os novos movimentos religiosos nos ensina sobre o sujeito hoje? Estudos de Psicologia, v.12, n.2. Disponível em http://www.scielo.br. Acesso em 13/12/2009.

MiJOLLA-MELLOR S. (2004). A necessidade de crer. São Paulo: Unimarco Editora.

MILLER, J. -A. (2004) Religião, psicanálise. Opção lacaniana Revista Internacional de Psicanálise, n.39, p.9-24.

MORANO, D. (1990) El psicoanálisis freudiano de la religión: Analisis textual y comentario crítico. Madri: Paulinas.

TEIXEIRA, A. (2007) "O nó ateu: do mito do Pai ao pai como sinthôme”, in: A soberania do inútil e outros ensaios de psicanálise e cultura. São Paulo: Annablume.

ZIZEK, S. (2003) "O real da ilusão cristã: notas sobre Lacan e a religião”, in SAFATLE, V. (Org.) Um limite tenso: Lacan entre a filosofia e a psicanálise. São Paulo: Unesp.

Claudia Maria Silva Moreira

claudiasmoreira@yahoo.com.br

Jeferson Machado Pinto

jefpinto@uai.com.br 